\title{
Speckle-tracking echokardiográfia a klinikai gyakorlatban
}

\author{
Kovács Attila', Ágoston Gergely²
}

\author{
${ }^{1}$ Semmelweis Egyetem, Városmajori Szív- és Érgyógyászati Klinika, Budapest \\ ${ }^{2}$ Szegedi Tudományegyetem, Általános Orvostudományi Kar, Családorvosi Intézet, Szeged \\ Levelezési cím: Dr. Ágoston Gergely, e-mail: agoston.gergely@med.u-szeged.hu
}

\begin{abstract}
A myocardium deformációját jellemző speckle-tracking echokardiográfia a klinikai kutatás területén gyakran alkalmazott módszer. A kutatások mellett azonban a napi gyakorlatban is terjedőben van, és a legtöbb echokardiográfiával foglalkozó kardiológus számára elérhető. A globális longitudinális strain diagnosztikus és prognosztikus értékkel rendelkezik több kardiológiai kórképben. Jelen összefoglalónkban a strain és strain rate képalkotás újdonságaira, valamint a gyakorlatban történő hasznosságukra összpontosítunk.
\end{abstract}

Kulcsszavak: echokardiográfia, deformációs képalkotás, speckle tracking, klinikai jelentőség

\section{Speckle-tracking echocardiography in clinical practice}

Deformation imaging by speckle-tracking echocardiography is a well-established and frequently used research tool. Beyond research, speckle-tracking echocardiography has become readily available for the clinical cardiologists. Among several parameters, global longitudinal strain has been shown to provide added diagnostic and prognostic value in various cardiovascular conditions. This review focuses on recent advances in the field of strain and strain rate imaging, and provides an overview on its current clinical applications.

Keywords: echocardiography, deformation imaging, speckle-tracking, clinical application

\section{Bevezetés}

Évtizedeken át a 2D és a Doppler-echokardiográfia jelentette a balkamra-funkció mérésének alapját. Napjainkban is sokszor hagyatkozunk az ejekciós frakció (EF) becslésére és a regionális falmozgászavarok megítélésére a balkamra-funkció vizsgálatakor. A hagyományos mérések megbízhatóak, viszont nagy interobszerver, sőt akár intraobszerver variabilitást mutatnak, az eredményt befolyásolja a vizsgáló szakértelme és tapasztalata is. Emiatt az echokardiográfiás technikák fejlesztésekor egyre inkább merül fel az igény az automatikus, félautomatikus és off-line kiértékelés lehetőségét biztosító módszerek megalkotására. Ilyen a speckle-tracking alapú strain képalkotás, amelynek használatát a klinikai gyakorlatban - a hagyományos paraméterek (EF) mellett - már az Európai Kardiovaszkuláris Képalkotó Társaság (EACVI) és az Amerikai Echocardiographiás Társaság (ASE) (1) is javasolja.

\section{A strain fogalma}

A strain, a myocardium egy szegmentumának hoszszváltozását írja le, a kiindulási hosszhoz képest, százalékban kifejezve. A strain rate, a strain értékének idő szerinti deriválásból származik, és azt mutatja, hogy a deformáció milyen sebességgel történik. A myocardium összehúzódása közben a deformáció összetett, bonyolult mozgással jellemezhető, azonban a klinikai gyakorlatban, kétdimenziós képalkotás során a deformáció modellezése egyszerübb módon történik, három strain-paraméter alkalmazásával. Ezek a radiális (sugárirányú) vastagodás és vékonyodás, valamint cirkumferenciális (körkörös) és longitudinális (hosszirányú) rövidülés és nyúlás. Megállapodás szerint a vastagodás és a nyúlás pozitív strain-értékeket vesz fel, a vékonyodás és a rövidülés pedig negatív strain-értékekkel jellemezhető. A strain értéke minden vizsgált kamrai vagy pitvari szegmentumban meghatározható. A szegmentális érté- 


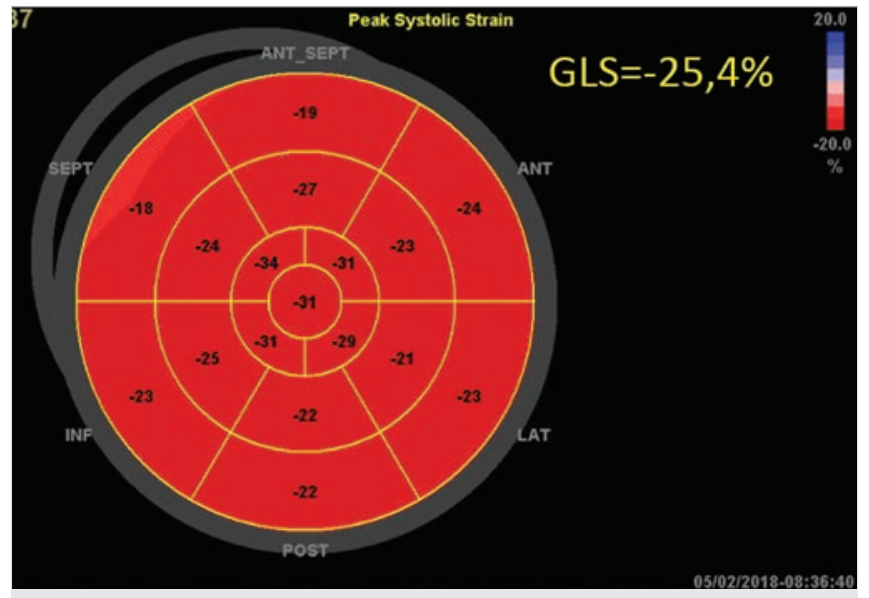

1. ÁBRA. Egészséges egyén globális longitudinális strain mintázata 17 szegmentumos bull's eye megjelenítésben

kek átlagolásával jutunk a globális strainekhez. A legbővebb irodalmi háttérrel rendelkező, klinikai gyakorlatban is a legelterjedtebb paraméter a csúcsi metszetekből, a longitudinális rövidülést leíró globális longitudinális strain (GLS) érték. Fiziológiás körülmények között értéke minden balkamra-szegmentumban eléri a -20\%-ot és az úgynevezett bulls' eye formában jeleníthető meg (1. ábra) (2). Fontos, hogy a myocardium deformációja nagyban függ az elő- és utóterheléstől, valamint a vizsgált szívüreg falának vastagságától.

\section{A speckle-tracking echokardiográfia használatának elméleti és gyakorlati alapja}

A 2D speckle-tracking echokardiográfia (STE) alkalmazása során egy adott myocardium szegmentum mintázatát (foltjait) követjük, a kétdimenziós, B-módú felvételen, képkockáról képkockára. A sík minden irányába követhető a kiválasztott myocardium terület deformációja, így a strain, a strain rate, az elmozdulás (displacement) és a sebesség is meghatározható. Az STE előnye a korábbi szöveti Doppler-technikával szemben, hogy a méréseinket nem befolyásolja az inszonáció iránya és a vizsgált képlet mérendő deformációs iránya által bezárt szög (3). Az STE-analízis alkalmával törekedni kell az optimális $2 \mathrm{D}$ képminőségre és a vizsgált képlet lehető legpontosabb geometriai leképezésére. STE gyakorlati használata során a következő technikai beállításokat kell figyelembe venni.

Mivel off-line végezzük a méréseket, a megelőzően rögzített $2 \mathrm{D}$-felvétel beállítása alapvetően meghatározza az analízis sikerességét, minőségét. A képkocka frissítési sebesség (FPS) magas kell, hogy legyen, lehetőleg 40 és 80 képkocka/másodperc intervallumban mozogjon (4). Alacsony képfrissítési sebességnél a képkockáról-képkockára történő analízis során a szoftver elveszítheti a mintázat követését, így kevésbé részletgazdag strain görbét, téves eredményt kapha- tunk. Magas képfrissítési sebesség alkalmazásával, tachycard szívmüködésnél is elkerülhető a túl alacsony mintavételezés (5). Az endocardium határa lehetőség szerint tisztán és egyértelműen kell, hogy ábrázolódjon. A szektor optimális mélységének és szélességének beállítása szintén nagyon fontos, a vizsgálni kívánt struktúra a szívciklusok során nem mozdulhat ki a képből. A felvételen lehetőség szerint ne legyenek mütermékek, hiszen ezek szintén rontják a követés minőségét. Csúcsi metszetben kerülni kell a csúcsi rövidülést (fore-shortening), mivel az torzíthatja az eredményeket, parasternális rövid metszetben pedig kizárólag szabályos kör átmetszetű bal kamrai leképezésből szabad mérni a radiális és cirkumferenciális deformációt.

\section{Balkamra-hipertrófia vizsgálata speckle-tracking echokardiográfiával}

Balkamra-hipertrófiát számos stimulus válthat ki, ilyen a rendszeres fizikai terhelés, a genetikai tényezők, a balkamra-nyomás-, és/vagy volumenterhelése, illetve különböző biokémiai mechanizmusok. A balkamra-hipertrófia korai stádiumában, jó bal kamrai EF mellett is lehet szisztolés mủködészavar, amely az esetek többségében tünetmentes, prognosztikai jelentősége azonban meghatározó. Továbbá, a hagyományos 2D echokardiográfiás vizsgálat csak korlátozott mértékben alkalmas a fiziológiás és patológiás balkamra-hipertrófia differenciálására. Ezzel szemben a speckle-tracking echokardiográfiának kiemelt jelentősége lehet, hiszen segíthet a különböző balkamra-hipertrófiák elkülönítésében, akár rámutathat raktározási betegség fennállására is. Öszszességében a speckle-tracking echokardiográfia a balkamra-funkció finom mechanikai eltéréseinek detektálására alkalmas, így jóval korábban, az ejekciós frakció csökkenése előtt, klinikailag panasz- és tünetmentes állapotban utalhat patológiás folyamat fennállására.

Fiziológiás balkamra-hipertrófia - „Sportszív" Az adaptációs mechanizmusoknak köszönhetően az intenzív fizikai terhelés (föként) a bal kamra tömegének, falvastagságának és üregátmérőjének növekedéséhez vezet, amelyet a hétköznapi nyelven „sportszívnek” nevezünk. A sporttevékenység típusától függően a bal kamrai remodelling két alapvető formája különíthető el (6). Az állóképességet fokozó sporttevékenységek (futás, úszás, kerékpározás, labdarúgás, tenisz) csökkentik a szisztémás artériás rezisztenciát, növelik a vénás visszaáramlást, így elsősorban térfogatterhelést rónak a bal kamrára, ezáltal növelik a végdiasztolés- és verőtérfogatot, amely excentrikus balkamra-hipertrófiához vezet. A sportok másik nagy csoportját az erősítő, statikus terhelésủ sportágak alkotják, ahol a nyomásterhelésnek köszönhetően a bal kamra koncentrikus hipertrófiája alakul ki, üregének tágulata nélkül (7). A fenti adaptációs mechanizmusoknak köszönhetően a balkamra-dilatáció 
és -hipertrófia olyan mértékű lehet, amely patológiás bal kamrát utánoz, azonban sportolóknál a bal kamra szisztolés és diasztolés funkciója legtöbbször normális, vagy szupranormális. Különösen nagy kihívást jelent a 13 és 15 mm közötti falvastagság megítélése, hiszen ebben a szürke zónában a legnehezebb eldönteni, hogy fiziológiás, vagy kóros mértékű a hipertrófia. Élsportolóknál a falvastagság az esetek többségében nem éri el a $12 \mathrm{~mm}$-t és minden balkamra-szegmentumot érint. A bal kamra végdiasztolés átmérője megnő, az ejekciós frakció viszont a legtöbbször normális, és ehhez szintén normális, vagy szupranormális verőtérfogat társul (8). Kérdéses esetekben használhatjuk a dekondícionálást: sportolóknál 3 hónap után a bal kamra falvastagsága csökken, hipertrófiás cardiomyopathia esetén értelemszerüen ez nem következik be. Állóképességet fokozó sportokban a bal kamra diasztolés funkciója mindig normális, vagy szupranormális, az E/A arány típusosan 2 felett van és a szöveti Dopplerrel meghatározott szeptális és laterális e' hullám értéke megnő. A speckle- tracking echokardiográfia megjelenése az élsportolók vizsgálatában új dimenziót nyitott, hiszen a fizikai terhelésre adott adaptációs mechanizmusokat új szemszögböl elemezhetjük (9). Élsportolókban a GLS értéke normális, csak kisebb különbségek észlelhetőek az ülő életmódot folytató kontrollcsoportokhoz képest $(10,11)$. Markáns bal kamrai dilatáció esetén várható, hogy a kontrollcsoporttal szemben kissé csökkent, ám normál tartományba eső GLS-értékeket mérünk. Az állóképességi és erőnléti sportágak különbözősége a myocardium mechanikai mintázatában is megmutatkozhat: a GLS kismértékü csökkenését írták le hosszútávfutókban, míg testépítőkben a globális cirkumferenciális strain volt kisebb, amely a balkamra-hipertrófia mértékével mutatott összefüggést (12). Élsportoló strain analízise során mért GLS mintázatot a 2. ábra mutatja.

\section{Primer balkamra-hipertrófia - Hipertrófiás cardiomyopathia}

Az echokardiográfiás vizsgálatnak kulcsszerepe van a hipertrófiás cardiomyopathia diagnózisában és utánkövetésében. A balkamra-hipertrófia legtöbbször az interventrikuláris szeptum bazális szegmentumait érinti, azonban sokszor kiterjed a bal kamra többi falára is. Annak ellenére, hogy az ejekciós frakció hipertrófiás cardiomyopathiában normális, illetve szupranormális, az STE-analízis során csökkent strain-értékeket észlelünk, és ez sokszor a patológiás mértékủ balkamra-hipertrófia kialakulása előtt detektálható (13). A longitudinális strain értéke abban a lokációban csökken leginkább, ahol a hipertrófia a legnagyobb mértékű (14) (3. ábra). HCM-ben, az alacsony GLS a kamrai aritmiák és a szívelégtelenség kialakulásának tekintetében kedvezőtlen prognosztikus marker $(15,16)$.

\section{Szekunder balkamra-hipertrófiák}

A balkamra-hipertrófia kialakulásának elsődleges oka a fal feszülése, valamint az üreg volumen-túlterhelése. A Laplace-törvénynek megfelelően a falfeszülés egyenesen arányos az üreg nagyságával és a benne uralkodó nyomással, és fordítottan arányos a fal vastagságával. Az esetek többségében a balkamra-hipertrófiát nyomásterhelés okozza, ennek típusos példája az aortastenosis, vagy a magasvérnyomás-betegség. Térfogatterhelés esetén a megnövekedett bal kamrai volumen emeli a bal kamrai szisztolés nyomást és az utóterhelést, így kombinált nyomás- és volumenterhelés jelentkezik, amelynek következtében excentrikus hipertrófia alakul ki, ezt látjuk aortaregurgitációban.

Balkamra-hipertrófia vizsgálata hipertóniában A hipertóniás betegekre jellemző a koncentrikus balkamra-hipertrófia, diasztolés diszfunkcióval és megőr-

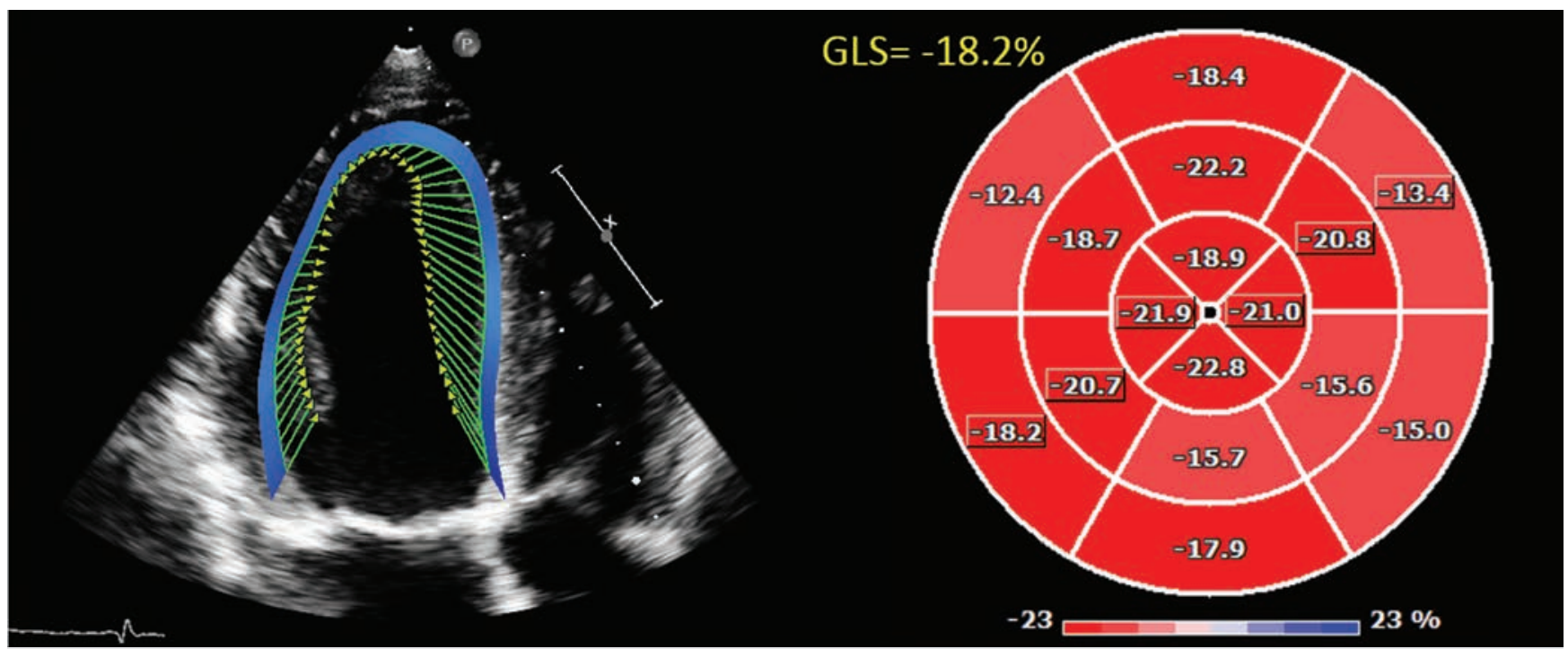

2. ÁBRA. Kajakos élsportoló GLS analízise. Tágabb bal kamra mellett (EDV 203 ml), az ejekciós frakció enyhén csökkent volt (48\%). Szív MR-vizsgálat egészséges sportszívet igazolt. Sportolókban, jelentősebb bal kamrai dilatáció esetén várható a deformációs paraméterek enyhe csökkenése 


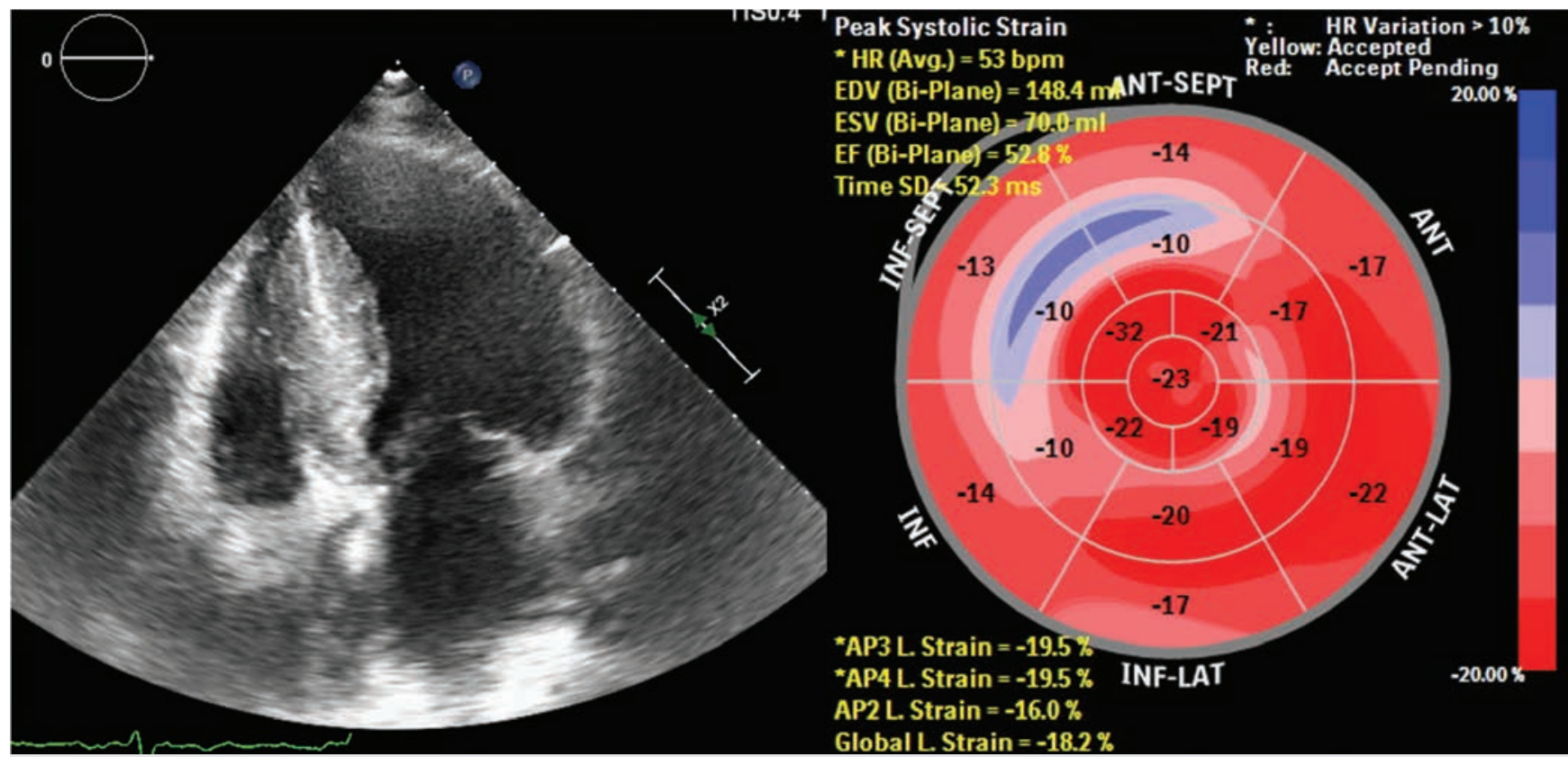

3. ÁBRA. Hipertrófiás cardiomyopathia (ASH) strain mintázata. A globális longitudinális strain értéke azokban a szegmentumokban a legalacsonyabb, ahol a hipertrófia a legkifejezettebb, a fenti ábrán az anterior és inferior szeptum középső szegmentuma

zött szisztolés funkcióval, amely egészen a betegség késői stádiumáig fennmarad. A TDI-technikával mért szeptális e' hullám típusosan csökken, és a csökkenés szeptálisan kifejezettebb, mint laterálisan (17). A speckle-tracking echokardiográfia során mért GLS-érték segít a hipertónia által okozott korai szisztolés diszfunkció kimutatásában, akár a balkamra-hipertrófia kialakulása előtt. A nyomásterhelés miatt a szeptum bazális részének funkciója károsodik elsőként, így a strain-érték ebben a szegmentumban csökken először (18). A GLS értékét leginkább a diasztolés diszfunkció mértéke határozza meg, és kevésbé függ a balkamra-hipertrófia, vagy az afterload emelkedésének mértékétöl. A szöveti Doppler csak balkamra-hi- pertrófia jelenléte esetén mutatja a szisztolés diszfunkciót, míg a GLS-érték balkamra-hipertrófia nélkül is jelzi (19). Hipertóniás beteg típusos GLS-mintázatát a 4. ábra mutatja. Számos más etiológiai tényező mellett a hipertónia igen jelentős faktor a megtartott ejekciós frakciójú szívelégtelenség (HFpEF) kialakulásában. A GLS HFpEF esetén is igazolt diagnosztikus és prognosztikus értékkel bír (20), amelyhez kutatások szerint a myocardium deformációjának örökletessége is hozzájárul ebben a betegcsoportban (21). Állatkísérletes HFpEF-modellen szoros korreláció volt fellelhető a szisztolés strain, strain rate és az invazív nyomás-térfogat-analízissel meghatározott kontraktilitás, az izovolumetriás relaxáció során mért strain rate és

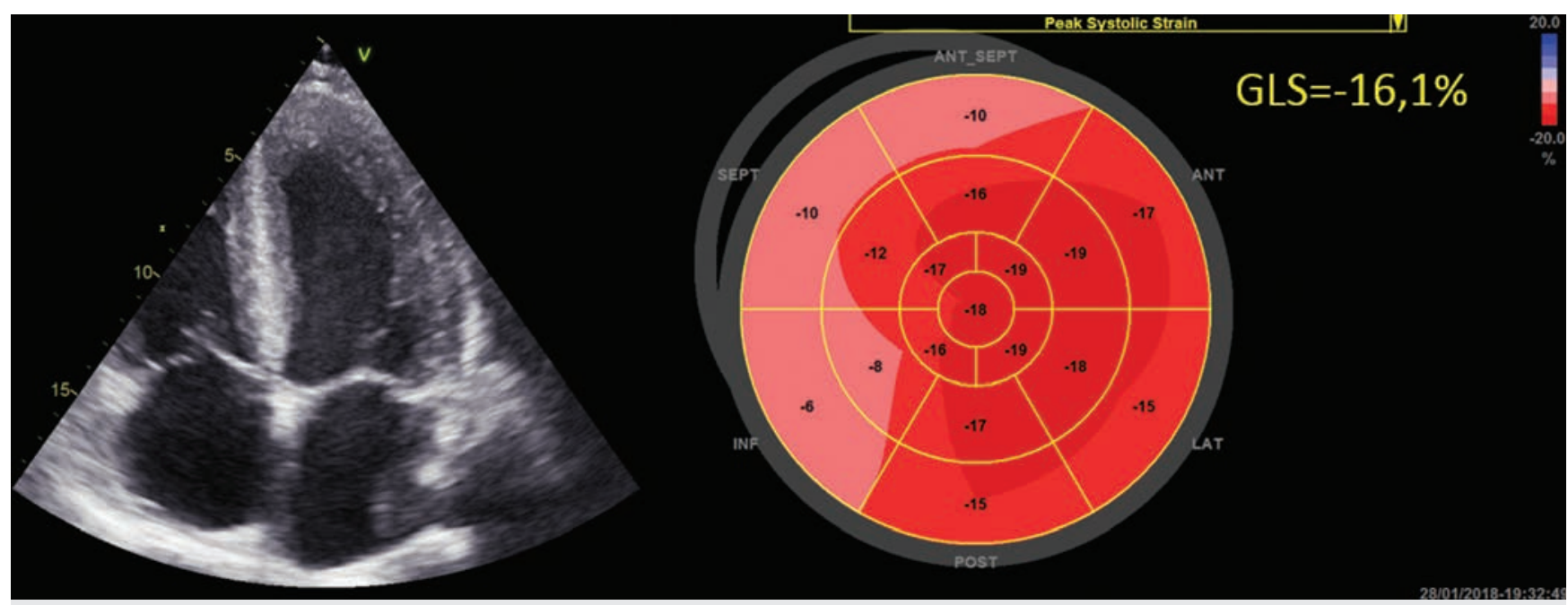

4. ÁBRA. Rosszul beállított hipertónia longitudinális strain mintázata. A szeptum és a hátsó fal vastagsága 17-17 mm. A longitudinális strain típusosan a bazális szegmentumokban alacsonyabb, azonban túlnyomórészt a szeptum bazális szegmentumai érintettek 


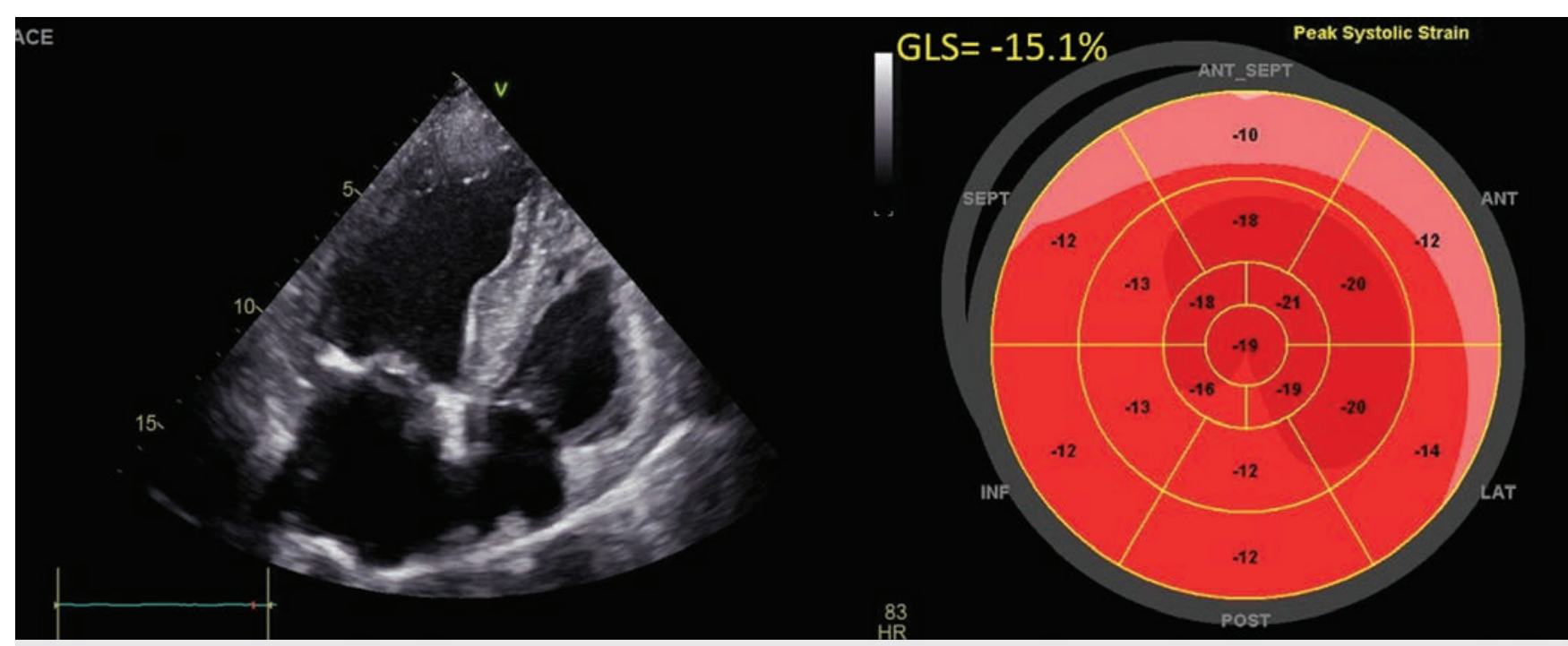

5. ÁBRA. Súlyos aortastenosisban (165/107 Hgmm) látható GLS mintázat a bazális szegmensek markánsabb deformáció csökkenésével. A bal kamrai ejekciós frakció $70 \%$

az aktív relaxáció, illetve a korai diasztolés strain rate és a bal kamrai stiffness, a cardiomyocyta átmérő és a fibrózis mértéke között (22).

\section{Balkamra-hipertrófia vizsgálata aortastenosisban}

Az aortabillentyű szükülete a leggyakoribb vitium a kor előrehaladtával. Az aortastenosis nemcsak az aortabillentyú betegsége, hanem kihat a perifériás erek és a bal kamra funkciójára is, még abban az esetben is, ha a bal kamra ejekciós frakciója sokáig megőrzött (23). Súlyos aortastenosisban, normál bal kamrai EF mellett a GLS értéke csökkent a kontrollcsoporthoz viszonyítva $(-17,8 \pm 3,5 \%$ vs. $21,1 \pm 1,8 \%$; $p<, 05)$, és az eltérés a bazális szegmentumokban észlelhető először (5. ábra). A GLS-csökkenés fordítottan arányos a balkamra-hipertrófia mértékével (24). Patofiziológiailag, az aortastenosisban tapasztalható folyamatos nyomásterhelés először a szívizomsejtek hipertrófiáját okozza, ezt követően a sejtek atrófiája, apoptózisa jelentkezik, majd a folyamatot a fibrotikus szövet kialakulása zárja, ezzel párhuzamosan a bal kamra funkciójának progresszív csökkenését láthatjuk.

Aortastenosisban a GLS progresszív módon csökken, ez a csökkenés az alacsony áramlás - alacsony grádiensü aortastenosis csoportban a legkifejezettebb. A rendelkezésre álló adatok alapján, a GLS-csökkenést aortastenosisban az afterload emelkedésének mértéke határozza meg. Amennyiben a GLS értéke megfelelő, a kontraktilitás és a myocardium integritása megőrzött, alacsony GLS esetén a szívelégtelenség kialakulásának esélye nagyobb, mivel irreverzibilis myocardium-károsodás, fibrózis valószínűsíthető (19).

\section{Bal kamra STE-analízise aortaregurgitációban}

Az aortaregurgitáció krónikus volumen-túlterhelést jelent, így progresszív balkamra-dilatációt, excentrikus hipertrófiát és szisztolés diszfunkciót okoz. A jelenleg érvényben lévő irányelvek a billentyűcserét súlyos re- gurgitáció és panasz esetében javasolják, illetve aszimptomatikus betegeknél, ahol a bal kamra végszisztolés átmérője $55 \mathrm{~mm}$ felett, az ejekciós frakció pedig $50 \%$ alatt van. $A$ jól meghatározott indikációk ellenére a mütét optimális megválasztásának ideje krónikus aortaregurgitációban továbbra is kérdéses, ugyanis a szisztolés diszfunkció az esetek közel egyharmadában megelőzi a klinikai tünetek kialakulását. Az STE klinikai alkalmazására aortaregurgitációban az adatok egyelőre korlátozott számban érhetőek el. Közepes és súlyos aortaregurgitációban végzett vizsgálatban a GLS szignifikánsan alacsonyabb volt azon betegek között, akiknél a szívelégtelenség tünetei észlelhetőek. Szívelégtelenség terápiát igénylő aortaregurgitációban, -18\%-os GLS a legjobb cut-off érték a betegség progressziója tekintetében, a - 14\%-os GLS-érték pedig kedvezőtlen prognózisra utal az aortabillentyű cserét követően (25).

\section{Bal kamra STE-analízise mitralis regurgitációban}

Mitralis regurgitációban a volumenterhelés miatt, a diasztolé ideje alatt a falfeszülés fokozódik, a szívizomsejtek megnyúlnak. A bal kamra kitágul, viszont a tágulat lehetővé teszi a verőtérfogat növekedését, így biztosítható az extra térfogat (a bal kamrának a szisztémás keringésbe és a bal pitvar felé „is” megfelelő vérmennyiséget kell biztosítani). Ennek következményeként klasszikus excentrikus hipertrófia alakul ki, vékony falakkal, tág bal kamra üreggel. A diasztolés funkciónak sokáig kedvez az excentrikus hipertrófia, így kompenzált mitralis regurgitációban gyakran szupranormális diasztolés funkciót mérünk (26). STE-analízissel a szubklinikus balkamra-diszfunkció kimutatható, mielőtt még a konvencionális módszerekkel szembetünő eltéréseket észlelünk. A mitralis regurgitáció korai stádiumában a GLS-érték normális, vagy szupranormális, mivel egyensúly alakul ki a megnőtt stroke-volumen és tágabb bal kamrai üreg között. A betegség elöre- 


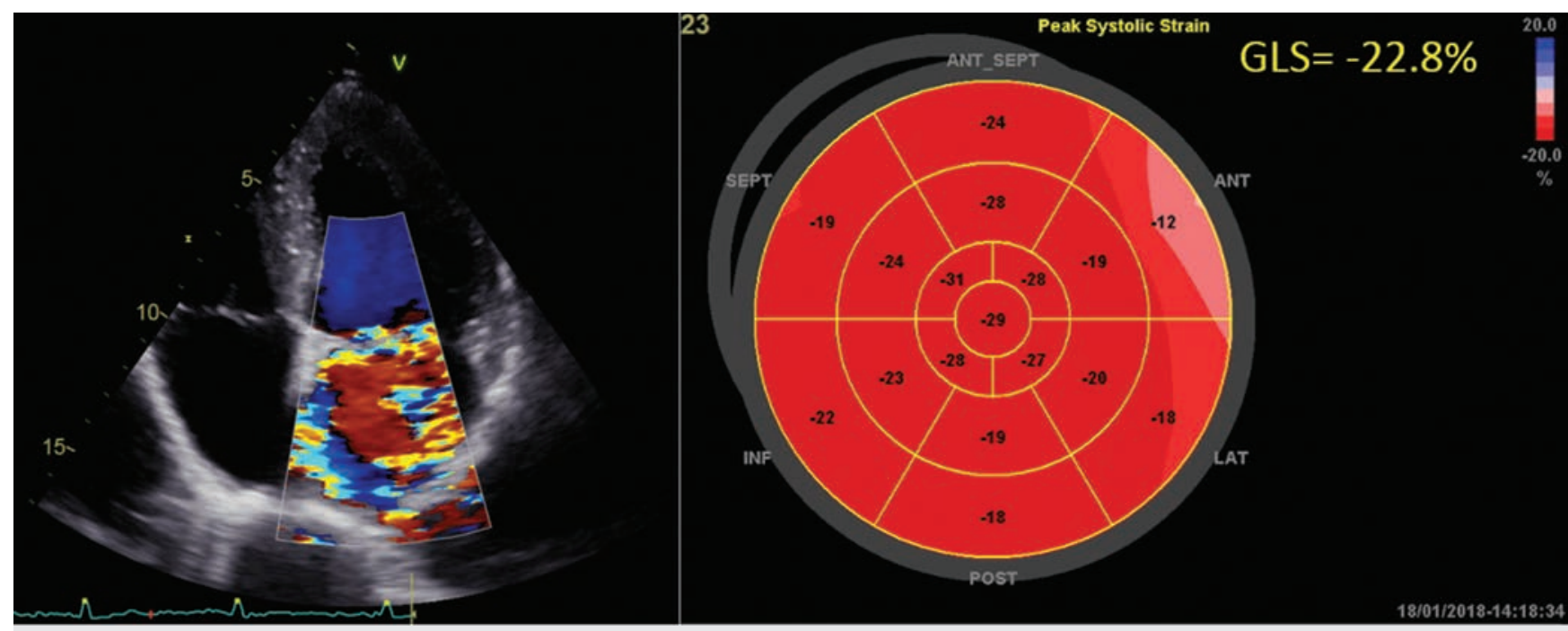

6. ÁBRA. Mitralis regurgitáció típusos longitudinális strain mintázata - a strain értéke a legtöbb szegmentumban átlag feletti (szupranormális), azonban a laterális és anterior fal bazális szegmentumán már csökkenésnek indult

haladtával viszont a szívizomzat károsodik, a GLS-érték csökken. A GLS-csökkenés először a bazális szegmentumokat és a laterális falat érinti (27) (6 ábra). Az STE-analízisnek kiemelt szerepe a van a műtét utáni prognózis becslésében, terheléses echokardiográfia során a nyugalmi és a terhelés csúcsán mért GLS-érték elörejelzi a mútét utáni balkamra-diszfunkciót. A terhelés csúcsán -18,5\%-nál kisebb GLS bizonyult a legjobb prediktornak a posztoperatív balkamra-diszfunkció kialakulásában (LVEF <50\%) (28).

\section{Infiltratív szívizombetegségek - \\ Szív amyloidosis}

Szív amyloidosisban, az amyloid lerakódás következményeként, a bal kamra falának megvastagodása, továbbá diasztolés és szisztolés funkciózavar észlelhető, amely később súlyos szívelégtelenség képében manifesztálódik. A definitív diagnózist általában az endomiokardiális biopszia jelenti, azonban echokardiográfiás vizsgálattal amyloidosisra specifikus jeleket detektálhatunk. A bal és a jobb kamra fala megvastagodott, a bal kamra ürege nem tágabb, de szembetűnő az emelkedett bal kamrai töltőnyomás következményeként kialakult tág bal pitvar. A kétdimenziós felvételen specifikus a "granular sparkling” jelensége, amely alatt a szívizomzat fényes és szemcsés mintázatát értjük (29). Szív amyloidosisban az STE-analízis akkor is képes a bal kamra finom diszfunkciójának vizsgálatára, amikor a hagyományos paraméterek nem mutatnak eltérést. A GLS-érték szív amyloidosisban csökken, a csökkenés a bazális szegmentumokban a legkifejezettebb, míg a csúcsban normáltartományban van („apical sparing” jelensége) (30) (7. ábra). Az apikális és a bazális szegmentumok közötti longitudinális strain-mintázat meghatározásához a relatív apikális longitudinális strain fogalmát vezették be, a képlet egyszerü, a mindennapokban könnyen használható: relatív apikális GLS=apikális GLS átlaga/középső és bazális szegmentumok GLS átlagának összege.

Optimális esetben a képlet eredménye 1 körüli érték, amely $93 \%$-os szenzitivitással és $82 \%$-os specificitással képes különbséget tenni a szív amyloidosis és a HCM, vagy a szív amyloidosis és hipertónia között (31).

\section{Fabry-betegség}

A Fabry-kór X-kromószomához köthető lizoszomális raktározási betegség, ahol globotriaosylceramid rakódik le a szívizomzatban, hipertrófiát, majd később fibrózist okozva. A GLS mintázta Fabry-kórban az amyloidosistól eltér, legtöbbször csupán a fibrózis helyén látunk GLS-csökkenést. A fibrózis gyakori lokalizációja a posterior és laterális fal bazális szegmentuma (32).

\section{Anabolikus szteroidhasználat}

Az anabolikus szteroidok a tesztoszteron szintetikus származékai, rendszeres használatuk sportolóknál, növeli az LDL-, csökkenti a HDL-szintet, valamint a szisztolés és diasztolés vérnyomást is emeli. Transztorakális 2D-echokardiográfiával jelentős koncentrikus balkamra-hipertrófia látható, enyhén csökkent szisztolés balkamra-funkcióval, az Ele' hányados pedig sokszor emelkedett. STE-analízissel jelentősen és diffúzan csökkent GLS-mintázatot látunk (33). Az anabolikus szteroid használatának abbahagyását követően a balkamra-hipertrófia nagyon lassan mérséklődik, ezzel szemben a GLS-érték gyorsabb javulása látható. A hipertrófia elhúzódó csökkenésének oka valószínűleg az anabolikus szteroidok közvetlen hatásának tulajdonítható, ugyanis az androgén receptorokhoz kapcsolódva közvetlen úton vált ki hipertrófiát (34). Az 1. táblázat az egyes betegségekre jellemző GLS-értéket és a GLS-mintázat típusos eloszlását mutatja (35). 


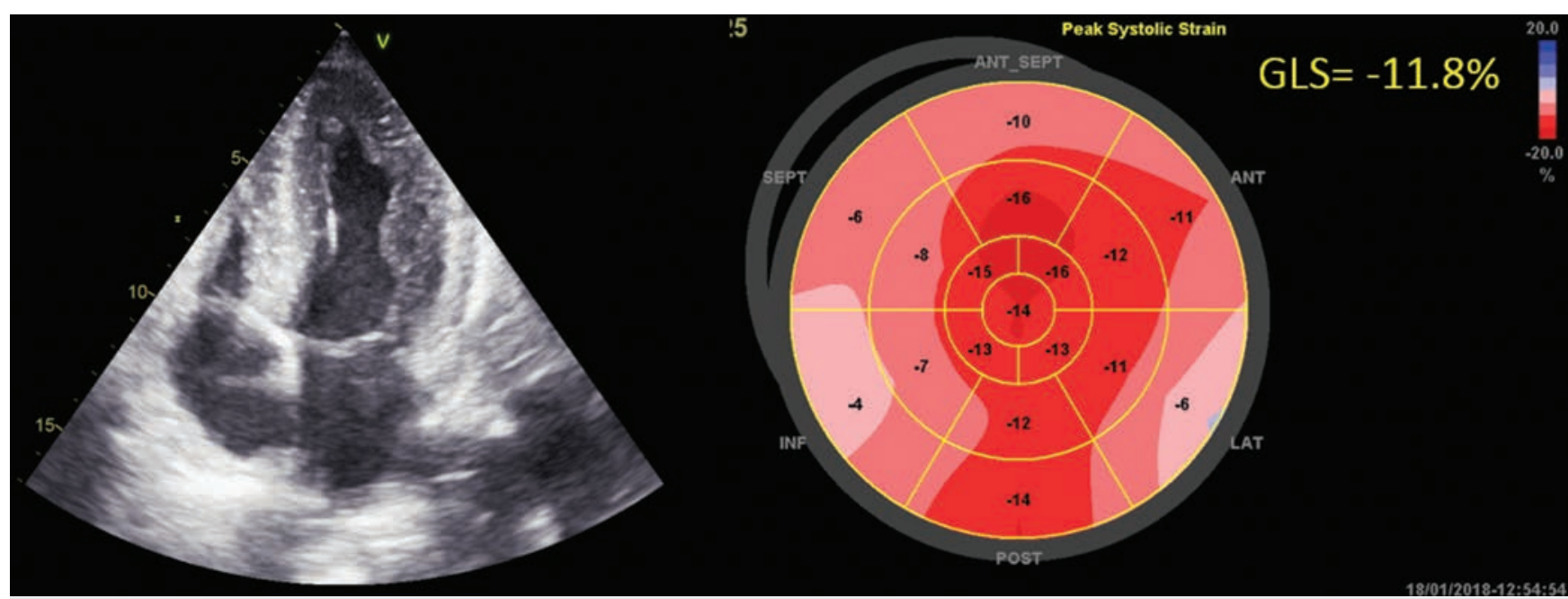

7. ÁBRA. Csökkent longitudinális strain-érték szív amyloidosisban. A strain-érték csökkenése a bazális szegmentumokban kifejezett, a csúcsban pedig közel normális értéket mutat (apical sparing)

\section{Onkológiai betegek}

A kardiovaszkuláris betegségek mellett a daganatos betegségek okozta morbiditásé és mortalitásé a vezető szerep hazánkban, a két terület közötti kapcsolódási pontok fontossága pedig magától értetődő. A kemoterápiás szerek okozta kardiotoxicitás jelentőségét először az antraciklinek bevezetése után ismerték fel. A technikai lehetőségekhez mérten a bal kamrai ejekciós frakció mérése volt az, ami a rutin klinikumba beépült és a balkamra-diszfunkció progressziójának, illetve regressziójának monitorozására szolgál mind a mai napig. Definíció szerint kemoterápia indukált kardiotoxicitásnak számít a bal kamrai ejekciós frakció több mint 10\%kal való csökkenése, abszolút értékben 53\% alá (36). I-es típusú kardiotoxicitásra példa az antraciklinek alkalmazása, ami dózisfüggő, irreverzibilis, sejtszintű károsodáshoz vezet. Korai felismerésével és kezelésével megakadályozható a bal kamrai remodelling és a szív- elégtelenség progressziója. A II-es típusú kardiotoxicitás példája a trastuzumab, káros hatását nem dózis függvényében fejti ki és hatása leggyakrabban reverzibilis. Az ejekciós frakció ismert limitációit figyelembe véve azonban - ahogyan számos más kórkép esetében is - a szubklinikus kardiális diszfunkció kimutatására fejlett technikákat kell, hogy segítségül hívjunk. A speckle-tracking technikával mért globális longitudinális strain immáron markáns irodalmi háttérrel rendelkezik a kardio-onkológia témakörében, és meghatározásának bizonyítottan addícionális értéke van (37). Ideális esetben a GLS értékét egy kezelés előtti állapothoz kellene viszonyítanunk. A kezelés elindítása előtti komplex kardiológia vizsgálat minden beteg esetén szükséges lenne, azonban tapasztalati tény, hogy ez gyakran nem valósul meg. Azoknál a betegeinknél azonban fokozottan kell törekednünk erre, akiknél nagy kockázatú a kemoterápia indukált kardiotoxicitás kialakulása: jelentős kardiovaszkuláris rizikófaktorokkal rendelkezők; igazolt

1. TÁBLÁZAT. Az egyes betegségekre jellemző GLS-értéket és a GLS-mintázat típusos eloszlása (35). GLS (globális longitudinális strain), GRS (globális radiális strain)

\begin{tabular}{|c|c|c|c|}
\hline Balkamra-hipertrófia oka & GLS-mintázat & Átlagos GLS-érték & GLS-csökkenés lokalizációja \\
\hline Sportoló & Normál & $-22,1 \pm 4,4 \%$ & Nincs \\
\hline Hipertrófiás cardiomyopathia & Csökkent & $-15,7 \pm 3,6 \%$ & Interventrikuláris szeptum \\
\hline Hipertónia & Normál majd csökkent & $-18,3 \pm 2,1 \%$ & Interventrikuláris szeptum \\
\hline Aortastenosis & Csökkent+ csökkent GRS & & Bazális szegmentumok \\
\hline - Low flow-low gradient & & $-11,6 \pm 3,4 \%$ & \\
\hline - Normal flow- high gradient & & $-13,6 \pm 3,2 \%$ & \\
\hline \multicolumn{4}{|l|}{ Mitralis regurgitáció } \\
\hline • kompenzált állapot & Normál vagy szupranormális & $-23,2 \pm 2,1 \%$ & \\
\hline • elörehaladott állapot & Csökkent & $-17,2 \pm 3,0 \%$ & Laterális fal bazális szegmentuma \\
\hline Aortaregurgitáció & Csökkent & $-17,5 \pm 3,1 \%$ & Diffúz \\
\hline Amyloidosis & Csökkent & $-9,1 \pm 4,0 \%$ & Apical sparing \\
\hline Fábry-betegség & Csökkent & $-18,3 \pm 3,1 \%$ & Bazális-posterolaterális \\
\hline Anabolikus szteroidhasználat & Csökkent & $-12,1 \pm 2,0 \%$ & Diffúz \\
\hline
\end{tabular}


bal kamrai diszfunkciós betegek; 65 év feletti betegek; illetve nagy dózisú I-es típusú, vagy kombináltan I-es és II-es típusú kardiotoxikus szer alkalmazása esetén. Az antraciklinek kardiotoxikus hatása néhány óra után kimutatható (38). Az elvárásoknak megfelelően, a speckle-tracking echokardiográfiával nyert paraméterek az ejekciós frakció csökkenését megelőzően jeleznek és a kemoterápia teljes időtartama alatt csökkent értékeket mutatnak. Megjegyzendő, hogy nem csupán a longitudinális, hanem a cirkumferenciális és radiális strain-értékek csökkenéséről is beszámolnak a közlemények, ugyanakkor a legtöbb adat a longitudinális strainről áll rendelkezésre (és ehhez a technikailag is optimálisabb mérési lehetősége is hozzájárul). A regionalitást illetően elsősorban a szeptális és csúcsi szegmensek érintettek, szubendokardiális-szubepikardiális különbségeket nem tár fel az irodalom (39). Kiemelendő azonban, hogy nem elsősorban a strain abszolút értéke diagnosztikus és prognosztikus jelentőségű, sokkal inkább a terápia megkezdése előtti értékhez viszonyított változása. A GLS 15\%-nál nagyobb relatív csökkenése jó eséllyel utal szubklinikus diszfunkcióra (36). Természetesen, a mérések gyártó-függő variabilitása miatt az utánkövetés során azonos technikai feltételek szükségesek, mind hardveres (ultrahangrendszer), mind szoftveres (speckletracking analízis program) terén. A strain-értékek csökkenése azonban nem csupán a kezelés közvetlen közelében, hanem a hosszútávon túlélő betegpopulációkban is felfedezhető (40). I-es típusú toxicitást okozó szerek esetében a terápia komplettálása után és azt követően 6 hónappal javasolt kontroll echokardiográfia (fokozott kockázatú betegek és nagy dózisok esetén akár egyes ciklusok között is), II-es típusú károsodást okozó szerek esetében pedig a terápia közben 3 havonta, komplettálását követően pedig 6 hónap múlva (36).

\section{Szívtranszplantáció}

Egyre növekvő számú szívtranszplantált betegeink az echokardiográfusok számára is komoly kihívást jelentenek. Mind a celluláris, illetve humorális rejekciós epizódok okozta - gyakran megtartott ejekciós frakcióval járó - szívizom-károsodás és globális bal kamrai funkcióvesztés, mind akár a krónikus allograft vasculopathia miatt kialakuló szegmentális falmozgászavar felismerése jogos elvárás. A fejlett ultrahangos technikák ebben szintén segítséget jelentenek és sokszor ezen betegek utánkövetésének sarokkövei lehetnek. Amíg celluláris rejekció esetén domináló szeptális falmozgászavar és longitudinális strain-csökkenés a vezető jel, humorális rejekció esetén egy globális és jóval larváltabb funkcióvesztés várható (41). Kiemelendő itt is az alapvonal meghúzása, azaz a kezdeti strain-értékek és mintázat meghatározása, amihez az utánkövetés során méréseinket viszonyíthatjuk. Az első évben a bal- és jobbkamra-funkció folyamatos javulása várható, a rejekciós epizódok azonban ennek a javulásnak az elmaradását eredményezik. A bal kamrai GLS értéke jól korrelál a rejekciós epizódok súlyosságával és számával, azonban ez az összefüggés az ejekciós frakció esetében nincs jelen (8. ábra) (42). Szintén közölték a GLS csökkenésének és a krónikus allograft vasculopathia jelenlétének és súlyosságának kapcsolatát (43). Mint a korai posztoperatív időszak legfontosabb meghatározója, a jobbkamra-funkció pontos mérése is feladat. Irodalmi adatok alapján ismert, hogy kizárólag a longitudinális funkcióra utaló paraméterek (pl. TAPSE) nem korrelálnak jól a jobb kamrai ejekciós frakcióval, így 3D-echokardiográfia hiányában törekednünk kell a FAC mérésére az utánkövetéses vizsgálatok során. A FAC ugyanis részben a radiális jobb kamrai kontrakciót is számsze-

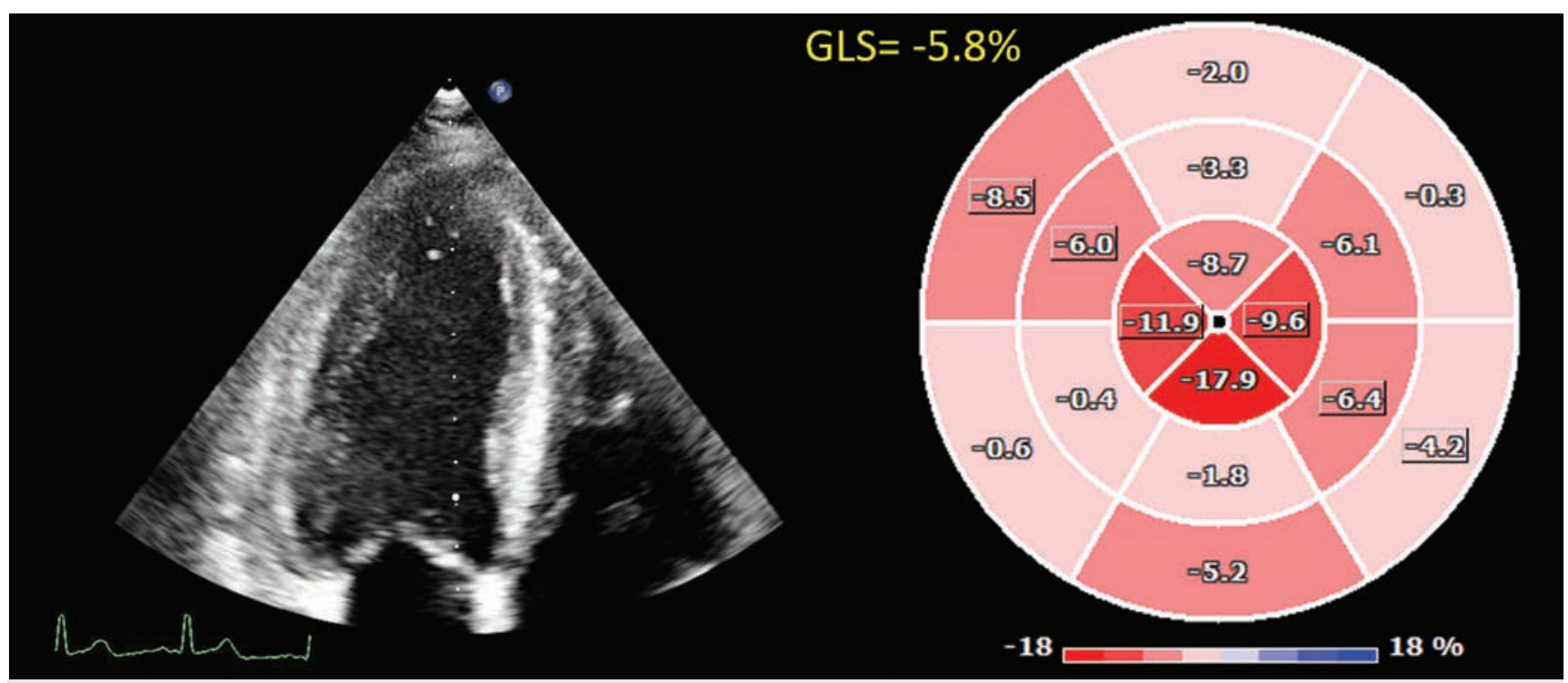

8. ÁBRA. Súlyos, kevert humorális és celluláris rejekció szívtranszplantáció után. Az ejekciós frakció csak enyhe-közepes fokban csökkent (45\%), azonban a longitudinális deformáció jelentősen károsodott az apikális szegmensek relatív megtartott rövidülésével 
rűsíti, amely abszolút domináns a globális funkció meghatározásában a korai posztoperatív időszakban, sőt, évekkel a szívtranszplantáció után is (44).

\section{Jobb kamra}

A bal kamrához viszonyítva a jobb kamra jóval összetettebb geometriával és funkcióval rendelkező szívüreg, echokardiográfiás megítélése ennek okán nagyobb kihívás (45). A speckle tracking mind a szegmentális és globális strain-értékek mérése útján, mind pedig a 3D jobb kamrai rekonstrukciók létrehozásához nyújtott technikai háttér útján jelentős előrelépést jelent a jobb kamrai geometria és funkció pontosabb feltérképezése terén. Egészen friss kutatások bizonyítják a jobb kamrai longitudinális strain hozzáadott, nem csupán diagnosztikus, hanem egyben prognosztikus értékét a TAPSE-val szemben $(46,47)$. Egy olasz munkacsoport 200 csökkent ejekciós frakciójú szívelégtelenségben szenvedő, azonban megtartott (>16 mm) TAPSE-vel rendelkező beteget vizsgált és követett átlagosan több, mint két évig. A jobb kamra szabad fali longitudinális strain független prediktora volt a mortalitást vagy szívelégtelenség hospitalizációt magában foglaló elsődleges végpontnak (46). Aritmogén jobb kamrai diszplázia esetén nemcsak a globális funkcióvesztés, hanem a regionális eltérések is felismerhetőekké válhatnak (9. ábra). A GLS és a szabad fali longitudinális strain egyaránt csökkent már a betegség korai fázisában is, sőt asszimptomatikus, releváns mutációt hordozó egyénekben is (48). Nem csupán a strain abszolút értékei, de a szegmentális „time-to-peak” értékek eltérései, amelyek a jobb kamrai mechanikus diszperziót jellemzik, értékes paraméterek lehetnek (49). 3D-echokardiográfiával a kórjelző lokális aneurizmák felismerése és interpretálása válhat könnyebbé, a 3D volumetriás lehetőség (EF számítás) mellett (50). Kellő tapasztalattal rendelkező centrumokban ajánlható tehát a fejlett echokardiográfiás technikák segítségül hívása. Aritmogén jobb kamrai diszpláziás betegeink utánkövetésében, illetve családtagjaik szürésében a jobb kamrai longitudinális strain értékes paraméternek látszik. Fontos megjegyezni, hogy a jobb kamra összetett mozgásmintázattal rendelkezik, ezért sokszor nem elegendő csupán azon paraméterek mérése, amelyek kizárólag a longitudinális rövidülésére utalnak (és ebből a szempontból a longitudinális strain sem kivétel). 3D-technikával lehetséges a radiális (ún. fújtató) mozgás számszerüsítése is, amelynek jelentős hozzájárulása van a jobb kamrai ejekcióhoz már egészségesekben is (51). Ezt szem előtt tartva szükséges tehát a radiális funkcióra legalább részben utaló paraméterek mérése (fractional area change - FAC). A transztorakális 3D-echokardiográfiával meghatározott jobb kamrai ejekciós frakció hozzáadott prognosztikus értékét szintén igazolták (52).

\section{Ko̊vetkeztetések}

A napjainkig felhalmozott irodalmi és klinikai adatok alapján úgy tűnik, a deformációs képalkotás az echokardiográfiás vizsgálat megkerülhetetlen részévé válhat. $A$ kardiovaszkuláris megbetegedések széles skálájában alkalmazható, diagnosztikus és prognosztikus jelentőséggel bír. Így nem meglepő, hogy a már jelenleg is érvényben lévő irányelvek a napi rutin szintjén javasolják a globális longitudinális strain mérését. Ha a szegmentális strainek abszolút értékeinek mérése technikai okokból még nem is, de az egyes kórállapotokra jellemző szegmentális mintázatok megismerése és keresése bátran ajánlható. A gyakorlati alkalmazás során azonban fontos megjegyezni, hogy a technika, mint minden más echokardiográfiás módszer hordozza magában a tévedés le-

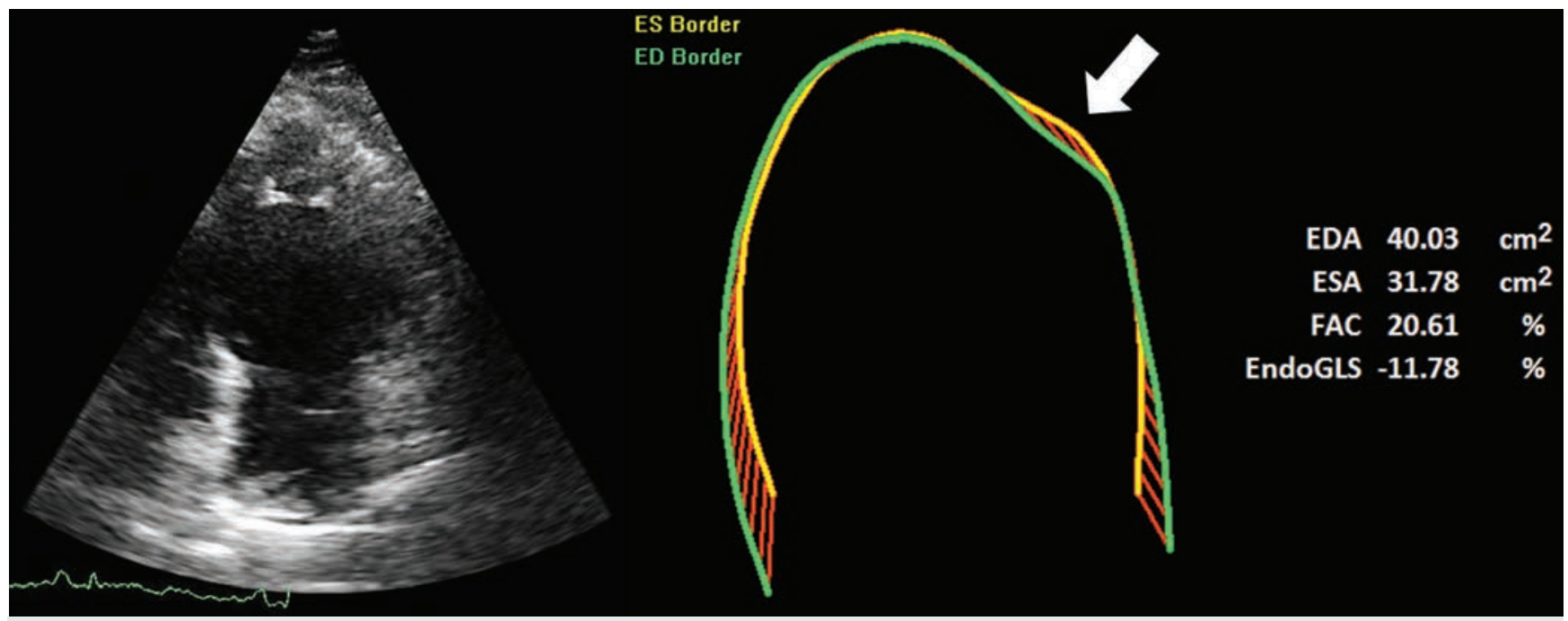

9. ÁBRA. Aritmogén jobb kamrai diszpláziás beteg. Jelentősen tágult, remodellált jobb kamra hiperechodenz moderátor köteggel. Csökkent globális longitudinális strain, az endokardiális kontúr követése egy lokális diszkinezist is felfed (nyíl) 


\section{hetőségét. A szoftver által generált automatikus és gyors eredményeket, a klinikai döntéshozatal elött mindig a klinikummal és egyéb más paraméterekkel, illetve mo- dalitásokkal vessük össze. Az automatizmusból adódó hibák, valamint az egyes gyártók között fennálló mérési standardok különbözősége jelenti a legnagyobb kihívást a deformációs képalkotás területén.}

\section{Irodalom}

1. Lang RM, Badano LP, Mor-Avi V, et al. Recommendations for cardiac chamber quantification by echocardiography in adults: an update from the American Society of Echocardiography and the European Association of Cardiovascular Imaging. European heart journal cardiovascular Imaging 2015; 16: 233-70. doi: 10.1016/j. echo.2014.10.003

2. Yingchoncharoen T, Agarwal S, Popovic ZB, Marwick TH. Normal ranges of left ventricular strain: a meta-analysis. Journal of the American Society of Echocardiography: official publication of the American Society of Echocardiography 2013; 26: 185-91. doi: 10.1016/j. echo.2012.10.008

3. Forsha D, Risum N, Rajagopal S, et al. The influence of angle of insonation and target depth on speckle-tracking strain. Journal of the American Society of Echocardiography: official publication of the American Society of Echocardiography 2015; 28: 580-6. doi: 10.1016/j.echo.2014.12.015

4. Mor-Avi V, Lang RM, Badano LP, et al. Current and evolving echocardiographic techniques for the quantitative evaluation of cardiac mechanics: ASE/EAE consensus statement on methodology and indications endorsed by the Japanese Society of Echocardiography. European journal of echocardiography: the journal of the Working Group on Echocardiography of the European Society of Cardiology 2011; 12: 167-205. doi: 10.1016/j.echo.2011.01.015

5. Amundsen $\mathrm{BH}$, Helle-Valle $\mathrm{T}$, Edvardsen $\mathrm{T}$, et al. Noninvasive myocardial strain measurement by speckle tracking echocardiography: validation against sonomicrometry and tagged magnetic resonance imaging. Journal of the American College of Cardiology 2006; 47: 789-93. doi: 10.1016/j.jacc.2005.10.040

6. Morganroth J, Maron BJ, Henry WL, Epstein SE. Comparative left ventricular dimensions in trained athletes. Annals of internal medicine 1975; 82: 521-4. doi: 10.7326/0003-4819-82-4-521

7. D'Andrea A, Bossone E, Radmilovic J, et al. The role of new echocardiographic techniques in athlete's heart. F1000Research 2015; 4 289. doi: 10.12688/f1000research.6745.1

8. George KP, Warburton DE, Oxborough D, et al. Upper limits of physiological cardiac adaptation in ultramarathon runners. Journal of the American College of Cardiology 2011; 57: 754-5. doi: 10.1016/j.jacc.2010.05.070

9. Kovacs A, Apor A, Nagy A, et al. Left ventricular untwisting in athlete's heart: key role in early diastolic filling? Int J Sports Med 2014; 35: 259-64. doi: 10.1055/s-0033-1349076

10. Caselli S, Montesanti D, Autore C, et al. Patterns of left ventricular longitudinal strain and strain rate in Olympic athletes. Journal of the American Society of Echocardiography: official publication of the American Society of Echocardiography 2015; 28: 245-53. doi: 10.1016/j.echo.2014.10.010

11. Lo ludice F, Petitto $M$, Ferrone $M$, et al. Determinants of myocardial mechanics in top-level endurance athletes: three-dimensional speckle tracking evaluation. European heart journal cardiovascular Imaging 2017; 18: 549-555. doi: 10.1093/ehjci/jew122

12. Szauder I, Kovacs A, Pavlik G. Comparison of left ventricular mechanics in runners versus bodybuilders using speckle tracking echocardiography. Cardiovasc Ultrasound 2015; 13: 7. doi: 10.1186/ s12947-015-0002-y

13. Losi MA, Nistri S, Galderisi M, et al. and Working Group of Echo- cardiography of the Italian Society of C. Echocardiography in patients with hypertrophic cardiomyopathy: usefulness of old and new techniques in the diagnosis and pathophysiological assessment. Cardiovascular ultrasound 2010; 8: 7. doi: 10.1186/1476-7120-8-7

14. Urbano-Moral JA, Rowin EJ, Maron MS, et al. Investigation of global and regional myocardial mechanics with 3-dimensional speckle tracking echocardiography and relations to hypertrophy and fibrosis in hypertrophic cardiomyopathy. Circulation Cardiovascular imaging 2014; 7: 11-9. doi: 10.1161/CIRCIMAGING.113.000842

15. Haland TF, Almaas VM, Hasselberg NE, et al. Strain echocardiography is related to fibrosis and ventricular arrhythmias in hypertrophic cardiomyopathy. European heart journal cardiovascular Imaging 2016; 17: 613-21. doi: 10.1093/ehjci/jew005

16. Reant P, Mirabel M, Lloyd $G$, et al. Global longitudinal strain is associated with heart failure outcomes in hypertrophic cardiomyopathy. Heart 2016; 102: 741-7. doi: 10.1136/heartjnl-2015-308576

17. Mancia G, Fagard R, Narkiewicz K, et al. Task Force for the Management of Arterial Hypertension of the European Society of $\mathrm{H}$ and the European Society of C. 2013 ESH/ESC Practice Guidelines for the Management of Arterial Hypertension. Blood pressure 2014; 23 : 3-16. doi: 10.1097/01.hjh.0000431740.32696.cc

18. Galderisi M, Lomoriello VS, Santoro A, et al. Differences of myocardial systolic deformation and correlates of diastolic function in competitive rowers and young hypertensives: a speckle-tracking echocardiography study. Journal of the American Society of Echocardiography: official publication of the American Society of Echocardiography 2010; 23: 1190-8. doi: 10.1016/j.echo.2010.07.010

19. Imbalzano E, Zito C, Carerj S, et al. Left ventricular function in hypertension: new insight by speckle tracking echocardiography. Echocardiography 2011; 28: 649-57. doi: 10.1111/j.15408175.2011.01410.x

20. Buggey J, Alenezi F, Yoon $\mathrm{HJ}$, et al. Left ventricular global longitudinal strain in patients with heart failure with preserved ejection fraction: outcomes following an acute heart failure hospitalization. ESC Heart Fail 2017; 4: 432-439. doi: 10.1002/ehf2.12159

21. Molnár AÁ, Kovács $A$, Kolossváry $M$, et al. Common genetic background of left ventricular global longitudinal strain and diastolic function: new insights into the understanding of heart failure with preserved ejection fraction? Eur Heart J (abstract) 2017; 38(S): 292293. doi: 10.1093/eurheartj/ehx502.P1446

22. Matyas $C$, Kovacs A, Nemeth BT, et al. Comparison of speckle-tracking echocardiography with invasive hemodynamics for the detection of characteristic cardiac dysfunction in type-1 and type-2 diabetic rat models. Cardiovasc Diabetol 2018; 17: 13. doi: 10.1186/ s12933-017-0645-0

23. Galli E, Lancellotti $P$, Sengupta PP, Donal E. LV mechanics in mitral and aortic valve diseases: value of functional assessment beyond ejection fraction. JACC Cardiovascular imaging 2014; 7 : 1151-66. doi: 10.1016/j.jcmg.2014.07.015

24. Lafitte $S$, Perlant $M$, Reant $P$, et al. Impact of impaired myocardial deformations on exercise tolerance and prognosis in patients with asymptomatic aortic stenosis. European journal of echocardiography: the journal of the Working Group on Echocardiography of the European Society of Cardiology 2009; 10: 414-9. doi: 10.1093/ ejechocard/jen299

25. Olsen NT, Sogaard P, Larsson HB, et al. Speckle-tracking echocardiography for predicting outcome in chronic aortic regurgitation during conservative management and after surgery. JACC Cardiovascular imaging 2011; 4: 223-30. doi: 10.1016/j.jcmg.2010.11.016 26. Corin WJ, Murakami T, Monrad ES, et al. Left ventricular passive diastolic properties in chronic mitral regurgitation. Circulation 1991; 83: 797-807. doi: 10.1161/01.CIR.83.3.797

27. Marciniak A, Claus $P$, Sutherland $G R$, et al. Changes in systolic left ventricular function in isolated mitral regurgitation. A strain rate imaging study. European heart journal 2007; 28: 2627-36. doi: 


\subsection{3/eurheartj/ehm072}

28. Lancellotti $P$, Cosyns B, Zacharakis D, et al. Importance of left ventricular longitudinal function and functional reserve in patients with degenerative mitral regurgitation: assessment by two-dimensional speckle tracking. Journal of the American Society of Echocardiography : official publication of the American Society of Echocardiography 2008; 21: 1331-6. doi: 10.1016/j.echo.2008.09.023

29. Cacciapuoti F. The role of echocardiography in the non-invasive diagnosis of cardiac amyloidosis. Journal of echocardiography 2015; 13: 84-9. doi: 10.1007/s12574-015-0249-1

30. Urbano-Moral JA, Gangadharamurthy D, Comenzo RL, et al. Three-dimensional Speckle Tracking Echocardiography in Light Chain Cardiac Amyloidosis: Examination of Left and Right Ventricular Myocardial Mechanics Parameters. Revista espanola de cardiologia 2015; 68: 657-64. doi: 10.1016/j.rec.2015.01.009

31. Phelan $D$, Collier $P$, Thavendiranathan $P$, et al. Relative apical sparing of longitudinal strain using two-dimensional speckle-tracking echocardiography is both sensitive and specific for the diagnosis of cardiac amyloidosis. Heart 2012; 98: 1442-8. doi: 10.1136/heartjnl-2012-302353

32. Kramer J, Bijnens B, Stork S, et al. Left Ventricular Geometry and Blood Pressure as Predictors of Adverse Progression of Fabry Cardiomyopathy. PloS one 2015; 10: e0140627. doi: 10.1371/journal. pone.0140627 doi: 10.1371/journal.pone.0140627

33. D'Andrea A, Caso P, Salerno G, et al. Left ventricular early myocardial dysfunction after chronic misuse of anabolic androgenic steroids: a Doppler myocardial and strain imaging analysis. British journal of sports medicine 2007; 41: 149-55. doi: 10.1136/ bjsm.2006.030171

34. Hassan NA, Salem MF, Sayed MA. Doping and effects of anabolic androgenic steroids on the heart: histological, ultrastructural, and echocardiographic assessment in strength athletes. Human \& experimental toxicology 2009; 28: 273-83. doi: 10.1177/0960327109104821.

35. D'Andrea A, Radmilovic J, Ballo P, et al. Working Group on Echocardiography of the Italian Society of $C$. Left ventricular hypertrophy or storage disease? the incremental value of speckle tracking strain bull's-eye. Echocardiography 2017; 34: 746-759. doi: 10.1111/ echo.13506

36. Plana JC, Galderisi M, Barac A, et al. Expert consensus for multimodality imaging evaluation of adult patients during and after cancer therapy: a report from the American Society of Echocardiography and the European Association of Cardiovascular Imaging. Eur Heart J Cardiovasc Imaging 2014; 15: 1063-93. doi: 10.1016/j. echo.2014.07.012

37. Thavendiranathan P, Poulin F, Lim KD, et al. Use of myocardial strain imaging by echocardiography for the early detection of cardiotoxicity in patients during and after cancer chemotherapy: a systematic review. J Am Coll Cardiol 2014; 63: 2751-68. doi: 10.1016/j. jacc.2014.01.073

38. Ganame J, Claus P, Eyskens B, et al. Acute cardiac functional and morphological changes after Anthracycline infusions in children. Am J Cardiol 2007; 99: 974-7. doi: 10.1016/j.amjcard.2006.10.063 39. Neilan TG, Jassal DS, Perez-Sanz TM, et al. Tissue Doppler imaging predicts left ventricular dysfunction and mortality in a murine model of cardiac injury. Eur Heart J 2006; 27: 1868-75. doi: 10.1093/eurheartj/ehI013

40. Cheung YF, Hong WJ, Chan GC, et al. Left ventricular myocar- dial deformation and mechanical dyssynchrony in children with normal ventricular shortening fraction after anthracycline therapy. Heart 2010; 96: 1137-41. doi: 10.1136/hrt.2010.194118

41. Clemmensen TS, Eiskjaer $H$, Kofoed-Nielsen $P B$, et al. Case of Acute Graft Failure during Suspected Humoral Rejection with Preserved Ejection Fraction, but Severely Reduced Longitudinal Deformation Detected by 2D-Speckle Tracking. Case Rep Transplant 2014; 2014: 173589. doi: 10.1155/2014/173589

42. Clemmensen TS, Logstrup BB, Eiskjaer H, Poulsen $\mathrm{SH}$. Serial changes in longitudinal graft function and implications of acute cellular graft rejections during the first year after heart transplantation. Eur Heart J Cardiovasc Imaging 2016; 17: 184-93. doi: 10.1093/ehjci/jev133

43. Clemmensen TS, Logstrup BB, Eiskjaer H, Poulsen SH. Evaluation of longitudinal myocardial deformation by 2-dimensional speckle-tracking echocardiography in heart transplant recipients: relation to coronary allograft vasculopathy. J Heart Lung Transplant 2015; 34: 195-203. doi: 10.1016/j.healun.2014.07.008

44. Lakatos BK, Tokodi M, Assabiny A, et al. Dominance of free wall radial motion in global right ventricular function of heart transplant recipients. Clin Transplant 2018. doi: 10.1111/ctr.13192

45. Lakatos B, Kovacs A, Tokodi M, et al. [Assessment of the right ventricular anatomy and function by advanced echocardiography: pathological and physiological insights]. Orv Hetil 2016; 157: 113946. doi: 10.1556/650.2016.30491

46. Carluccio E, Biagioli P, Alunni G, et al. Prognostic Value of Right Ventricular Dysfunction in Heart Failure With Reduced Ejection Fraction: Superiority of Longitudinal Strain Over Tricuspid Annular Plane Systolic Excursion. Circ Cardiovasc Imaging 2018; 11: e006894. doi: 10.1161/CIRCIMAGING.117.006894

47. Nagy VK, Szeplaki G, Apor A, et al. Role of Right Ventricular Global Longitudinal Strain in Predicting Early and Long-Term Mortality in Cardiac Resynchronization Therapy Patients. PLoS One 2015; 10: e0143907. doi: 10.1371/journal.pone.0143907

48. Teske AJ, Cox MG, Te Riele AS, et al. Early detection of regional functional abnormalities in asymptomatic ARVD/C gene carriers. J Am Soc Echocardiogr 2012; 25: 997-1006. doi: 10.1016/j. echo.2012.05.008

49. Saberniak J, Leren IS, Haland TF, et al. Comparison of patients with early-phase arrhythmogenic right ventricular cardiomyopathy and right ventricular outflow tract ventricular tachycardia. Eur Heart J Cardiovasc Imagin 2017; 18: 62-69. doi: 10.1093/ ehjci/jew014

50. Haugaa KH, Basso C, Badano LP, et al. Scientific Documents Committee EBm, external r, Eacvi Scientific Documents Committee $\mathrm{EBm}$ and external r. Comprehensive multi-modality imaging approach in arrhythmogenic cardiomyopathy-an expert consensus document of the European Association of Cardiovascular Imaging. Eur Heart J Cardiovasc Imaging 2017; 18: 237-253. doi: 10.1093/ehjci/ jew229

51. Lakatos B, Toser Z, Tokodi M, et al. Quantification of the relative contribution of the different right ventricular wall motion components to right ventricular ejection fraction: the ReVISION method. Cardiovasc Ultrasound 2017; 15: 8. doi: 10.1186/s12947-017-0100-0

52. Nagata Y, Wu VC, Kado Y, et al. Prognostic Value of Right Ventricular Ejection Fraction Assessed by Transthoracic 3D Echocardiography. Circ Cardiovasc Imaging 2017; 10: doi: 10.1161/CIRCIMAGING.116.005384. 